\title{
An experimental study to test the haemostatic effect of Aloe vera
}

\author{
Ramesh H. ${ }^{1 *}$, Jyothi C. H. ${ }^{2}$
}

${ }^{1}$ Department of Pharmacology, Karnataka Institute of Medical Science, Hubli, Karnataka, India ${ }^{2}$ Department of Pharmacology, JJM Medical College, Davanagere, Karnataka, India

Received: 01 March 2019 Accepted: 08 March 2019

*Correspondence to: Dr. Ramesh H., Email: kimsramesh@ yahoo.co.in

Copyright: () the author(s), publisher and licensee Medip Academy. This is an openaccess article distributed under the terms of the Creative Commons Attribution NonCommercial License, which permits unrestricted noncommercial use, distribution, and reproduction in any medium, provided the original work is properly cited.

\begin{abstract}
Background: Blood clotting is a process which prevents blood loss during injuries. Blood clots even when it is coming out from the blood vessels. Aloe vera is a perennial plant found all over India. It is commonly used in traditional system of medicine for treatment of wound healing, mouth ulcers, constipation, skin wrinkles and diabetes mellitus It is also used as antioxidant and antimicrobial agent. As it is used in traditional system of medicine for wound healing, this study was under taken to test the possible haemostatic effect of aloe vera.
\end{abstract}

Methods: 12 rats were divided into two groups (control and test) with 6 rats in each group. Determination of Bleeding Time (BT), rat tail was warmed for one minute in water at $40^{\circ} \mathrm{C}$ and then dried. A small cut was made in the middle of the tail with a scalpel. In test group, a drop of aloe vera leaf extract was applied on the injured area immediately after making the cut in the middle of the tail, where as in the control group nothing was applied, and BT estimated. Determination of Clotting Time (CT), 12 test tubes were arranged in water bath at $37^{\circ} \mathrm{C}$. Control Group: $0.4 \mathrm{ml}$ of blood was collected from each rat in the control group and added to 6 test tubes kept in the water bath. Test group: For the remaining 6 test tubes $0.1 \mathrm{ml}$ of aloe vera leaf extract was added. $0.4 \mathrm{ml}$ of blood collected from the test group was added to these test tubes. The CT was estimated for both control group and test group.

Results: The results were statistically analyzed by using unpaired t-test. The reduction in BT and CT for test group was statistically highly significant $(\mathrm{p}<0.001)$ compared to control group.

Conclusions: In this study aloe vera leaf extract significantly reduced both BT and $\mathrm{CT}$ in the test group.

Keywords: Aloe vera, Albino rats, Bleeding time, Clotting time, Haemostatic effect

efficient haemostatics could improve the management of bleeding. Hence there is a constant scope for better new haemostatics. Aloe vera is a perennial plant with a whorl of elongated and pointed leaves. It belongs to the family Liliaceae. It is found all over India. The peripheral bundle sheath cells contained the bitter yellow sap, commonly termed as aloe juice which exudes from the leaves when they are cut. The epidermis of the leaves has a thick cuticle and beneath is a zone of chlorenchyma. The mucilaginous tissue made up of large thin-walled mesophyll cells in the center of the leaf is called aloe vera gel and this gel is 
responsible for many of medicinal properties of aloe vera reported in folk medicine. ${ }^{6}$ Active Constituents of aloe vera include Barbalin, isobarbolin, saponins, aloin, and emodin. ${ }^{7}$

It also contains minerals like zinc, calcium, magnesium and copper. ${ }^{8}$ Aloe vera is commonly used in traditional system of medicine for treatment of wound healing, mouth ulcers, constipation, skin wrinkles and diabetes mellitus. It is also used as antioxidant, as mouth wash to prevent dental plaques and antimicrobial agent. ${ }^{9}$ As it is used in traditional system of medicine for wound healing, this study was under taken to test the possible haemostatic effect of aloe vera.

\section{METHODS}

\section{Animals}

There were 12 healthy albino rats of wistar strain of either sex weighing between 200-250 g were selected from central animal house of JJM Medical College Davanagere, Karnataka, India. The animals were housed under standard conditions and were provided food and water ad libitum. The study was approved by the institutional animal ethics committee.

Aloe vera plant specimen was identified in the department of Botany, DRM Science College. Davanagere, Karnataka, India. Study period was August 2016 to November 2016.

\section{Preparation of Aloe vera leaf extract}

Fresh aloe vera leaves were collected. The rind was selectively removed, and the colorless parenchyma was ground in a blender and centrifuged at 10,000rpm to remove the fibers. The supernatant was lyophilized and stored at $4^{\circ} \mathrm{C} .12$ rats were divided into two groups (control and test) with 6 rats in each group.

\section{Determination of Bleeding Time $(B T)^{10}$}

In control group, the rat tail was warmed for one minute in water at $40^{\circ} \mathrm{C}$ and then dried. A small cut was made in the middle of the tail with a scalpel. Bleeding time started when the first drop of blood touched the circular filter paper. It was checked at $30 \mathrm{sec}$ intervals until the paper no longer stained with blood. The time taken for bleeding to stop was recorded for each rat and the average was taken as bleeding time. In test group, after making a small cut in the middle of the tail with scalpel and blood had started coming out, a drop of aloe vera leaf extract was dropped on the injured site and bleeding time was recorded in the same way as in control group.

\section{Determination of Clotting Time $(C T)^{11}$}

There were 12 test tubes arranged in water bath at $37^{\circ} \mathrm{C}$. $0.1 \mathrm{ml}$ of aloe vera leaf extract was added to six test tubes (test group), while nothing was added to the remaining 6 test tubes (control group). Blood was collected directly from the heart of each rat after ether anesthesia. $0.4 \mathrm{ml}$ of blood collected from each rat was then delivered into each tube. The stopwatch was started immediately after the blood started flowing from the syringe and tubes were continually tilted at $40 \mathrm{sec}$ intervals until blood in them stopped flowing when tilted at an angle of $90^{\circ}$. The average of the clotting time of each group was recorded.

\section{Statistical analysis}

The results were expressed as mean \pm SEM and the results were analyzed by unpaired t- test. A p value $<0.05$ was considered statistically significant.

\section{RESULTS}

Table 1 shows the effect of Aloe vera leaf extract on bleeding time. The bleeding time was significantly reduced in test group as compared to control group. The mean bleeding time for control group was $179.67 \pm 1.33 \mathrm{sec}$ while that for test group was $159.5 \pm 1.48 \mathrm{sec}(\mathrm{p}<0.001)$.

Table 1: Effect of Aloe vera on bleeding time.

\begin{tabular}{|llr|}
\hline Group & $\begin{array}{l}\text { Bleeding Time (in } \\
\text { seconds) }\end{array}$ & p-value \\
\hline Control group & $179.67 \pm 1.33$ & $<0.001$ \\
\hline Test group & $159.5 \pm 1.48$ & \\
\hline
\end{tabular}

Table 2 shows the effect of Aloe vera leaf extract on clotting time. The clotting time was significantly reduced in test group as compared to control group. The mean clotting time for control group was $526.17 \pm 1.89 \mathrm{sec}$ that for test group was $410 \pm 1.90 \mathrm{sec} p<0.001)$.

Table 2: Effect of Aloe vera on clotting time.

\begin{tabular}{|lll|}
\hline Group & Clotting Time (in seconds) & p-value \\
\hline $\begin{array}{l}\text { Control } \\
\text { group }\end{array}$ & $526.17 \pm 1.89$ & $<0.001$ \\
\cline { 1 - 2 } Test group & $410 \pm 1.90$ & \\
\hline
\end{tabular}

\section{DISCUSSION}

This study was undertaken to evaluate the haemostatic activity of the aloe vera leaf extract with primary interest on how it affects bleeding time and clotting time respectively. Bleeding time is a measure of blood coagulation. It evaluates the vascular and platelet responses associated with hemostasis. In this study the bleeding time in control group was $179.67 \pm 1.33$ seconds and in test group was $159.5 \pm 1.48$ seconds $(\mathrm{p}<0.001)$. This study showed that aloe vera leaf extract significantly reduced bleeding time. Aloe vera leaf extract may be either acting on the integrity of the blood vessel or enhancing the formation of platelet plug to reduce BT. As aloe vera contains zinc which is an astringent may be astringent property of zinc is responsible for reduction of bleeding 
time. But there are few conflicting results to this finding. Kamal Kishore in his study, "effect of aloe vera on thrombosis in mice" has shown that Aloe vera significantly increased bleeding time in albino mice and it was concluded that increase in bleeding time was because of antioxidant property of aloe vera. ${ }^{12}$

Clotting Time is another measure of blood coagulation. It is the time required for a sample of blood to coagulate in vitro under standard conditions. Blood clotting occurs at the point of injury to control bleeding from blood vessels. The coagulation of the blood is initiated by the blood platelets. Calcium ions are required for the promotion and

In this study the clotting time in control group was $526.17 \pm 1.89$ seconds and in test group was $410 \pm 1.90$ seconds $(p<0.001)$. It indicates significant reduction of clotting time by aloe vera compared to control group. Aloe vera contains calcium and may be because of this there is enhancement of the coagulation of blood reducing the clotting time. In a study conducted by Mehta $\mathrm{JH}$ et al, 10 Indian herbs were evaluated for haemostatic activity. In this study it was shown that aloe vera reduced the clotting time by $24.7 \%$ indicating significant haemostatic activity of aloe vera. ${ }^{13}$ This study supports our finding that aloe vera leaf extract reduce clotting time. But in contrast to these findings, in a study by Dapper DV et al, it is reported that aloe vera prolonged the clotting time and inhibit blood clotting via both intrinsic and extrinsic pathways. ${ }^{14}$ Therefore further detailed studies are required to establish the haemostatic effect of aloe vera.

Funding: No funding sources Conflict of interest: None declared

Ethical approval: The study was approved by the Institutional Animal Ethics Committee

\section{REFERENCES}

1. Ryu JK, Petersen MA, Murray SG, Baeten KM, Meyer-Franke A, Chan JP, et al. Blood coagulation protein fibrinogen promotes autoimmunity and demyelination via chemokine release and antigen presentation. Nature communications. 2015 Sep 10;6:8164.

2. Chapin JC, Hajjar KA. Fibrinolysis and the control of blood coagulation. Blood reviews. 2015;29(1):17-24.

3. Sui J, Wang BC and Yu ZW. A novel haemostatic model with triple protective functions. Med Hypotheses. 2009;72:186-7.
4. Kozen BG, Kircher SJ, Henao J, Godinez FS, Johnson AS. Alternative hemostatic dressing: comparison of CELOX. Hem Con and Quik Clot. Acad Emerg Med. 2008;15:74-81.

5. Wedmore I, McManus JG, Pusateri AE, Holcomb JB. A special report on the chitosan - based hemostatic dressing: experience in current combat operations. $\mathbf{J}$ Trauma. 2006;60:655-8.

6. Subramanian S, Kumar SD, Arulselvan P, Senthilkumar GP, Rao MUS. Evaluation of Antiulcerogenic Potential of Aloe vera Leaf Gel Extract Studied in Experimental Rats. J Pharmacol Toxicol. 2007;2:85-97.

7. Moghaddasi SM, Verma SK. Aloe vera their chemicals composition and applications: A review. Int J Biol Med Res. 2011;2(1):466-71.

8. Surjushe A, Vasani R, Saple DG. Aloe vera: a short review. Ind J Dermatol. 2008;53(4):163-6.

9. Kar SK, Bera TK. Phytochemical constituents of aloe vera and their multifunctional properties: A comprehensive review. IJPSR. 2018;9(4):1416-23.

10. García-Manzano A, González-Llaven J, Lemini C, Rubio-Póo C. Standardization of rat blood clotting tests with reagents used for humans. Proceedings of the Western Pharmacology Society. 2001;44:153-5.

11. Weremfo A, Adinortey MB, Pappoe ANM. Hemostatic Effect of the stem juice of Musa paradisiaca L. (Musaceae) in guinea pigs. Advances in Biological Research. 2011;5(4):190-2.

12. Kamal Kishore. Effect of Aloe vera (Aloe barbadensis) on thrombosis in mice. Pharmacologia. 2015;6:347-54.

13. Mehta JH, Kularni CG, Jadhav ST, Deshpande AM, Bhise SB. Evaluation of Indian herbs for haemostatic activity. IJRPC. 2013;3(4):6-10.

14. Dapper DV, Achinike PN, Gwotmut MD. The effects of Aloe vera [gel] on clotting time, prothrombin time and plasma fibrinogen concentration in albino Wistar rats. Port Harcou Med J. 2007;2(1):56-60.

Cite this article as: Ramesh $\mathrm{H}$, Jyothi $\mathrm{CH}$. An experimental study to test the haemostatic effect of Aloe vera. Int J Basic Clin Pharmacol 2019;8:717-9. 